Original Research

\title{
How Do People Living with HIV Acquire HIV Related Information: A Qualitative Evaluation of Jakarta Setting
}

\author{
Mahathir Mahathir ${ }^{1}$, Wiwin Wiarsih ${ }^{2}$, and Henny Permatasari ${ }^{2}$ \\ ${ }^{1}$ Faculty of Nursing Universitas Andalas, West Sumatra, Indonesia \\ ${ }^{2}$ Faculty of Nursing, Universitas Indonesia, West Java, Indonesia
}

\begin{abstract}
Introduction: People living with HIV are fully aware of their risk behavior and future threats that might arise. The rapid progress of HIV serves the population with many options of healthcare services and treatments. Insufficient knowledge and information will only lower the outcomes of HIV eradication efforts. The ultimate goals to eradicate HIV are to upscale status notification and treat all with appropriate antiretroviral and viral suppression, but it needs sufficient information to administer. Programs and interventions have already been proposed, but an inquiry is needed to ensure all the information is actually there. The study aimed to explore the experience of people living with HIV acquiring HIV-related information.
\end{abstract}

Methods: This study used phenomenological qualitative study and in-depth interviews were conducted to 12 people living with HIV. Semi-structured questions were delivered to all participants which explored their tangible experience in terms of nurturing sufficient HIV-related information.

Results: The study found four consequential themes: non-government organizations play a major role in HIV education, peers are a comfortable platform to discuss, it is all over the media and healthcare personnel are a source of knowledge.

Conclusion: The distribution of HIV information and knowledge is now widespread. This situation marks part of the success in fighting HIV. Remarkable attempts can be maintained by optimizing the viable option of information delivery.

\section{ARTICLE HISTORY}

Received: May 27, 2020

Accepted: July 20, 2020

\section{KEYWORDS}

HIV knowledge; people living with HIV; qualitative study

\section{CONTACT}

Mahathir Mahathir

$\triangle$ mahathirmahat@nrs.unand.ac.i $\equiv$ Faculty of Nursing Universitas Andalas, West Sumatra, Indonesia

Cite this as: Mahathir, M., Wiarsih, W., \& Permatasari, H. (2019). How Do People Living With HIV Acquire HIV Related Information: A Qualitative Evaluation of Jakarta Setting. Jurnal Ners, 15(2). 126-134. doi:http://dx.doi.org/10.20473/in.v15i2.19432

\section{INTRODUCTION}

As of today, at least 32 million people have died as devastating consequences of HIV and AIDS since the start of the epidemic (UNAIDS, 2019). In order to achieve the 2030 target urgent pressing needs have to be fulfilled (UNAIDS, 2020). Various strategies will be provided with global solidarity, evidence-based action and multi stakeholders' partnerships in order to attain HIV treatment for all (UNAIDS, 2014). The progress toward sustainable development goals of health and wellbeing reported that there is strong and steady national and global financial commitment, the acceleration of evidence-based HIV prevention, testing and treatment programs availability among different countries. The total incidence rate of HIV incidence has declined by 22\% since 2010 (UN, 2019). Mortality caused by AIDS-related disease is also declining globally, but both of those achievements are far away from the target. HIV prevention, testing and treatment needs to be accelerated and focus on analyzing the gap of implementation (World Health Organization, 2019).

The HIV burden is still haunting most of countries worldwide, particularly for low and middle income countries (Haakenstad et al., 2019). The HIV global statistic data show 37.9 million people are now living with HIV, 1.7 million people are newly infected with the virus and 770.000 of them died caused by HIVrelated illness. It expected around 24.5 million people living with HIV are accessing antiretroviral therapy (UNAIDS, 2019). There are 13 million numerical gaps 
of people living with HIV not possessing antiretroviral treatment. Indonesia has been known as the fourth largest number of HIV new infections per year. Indonesia is the only country in the Asia Pacific region which has rapid increasing of HIV prevalence (Januraga et al., 2018). In the HIV statistics, Indonesia alone recorded 640,000 people affected by the virus, at least 46,000 people who are newly infected in the most recent year, and 38,000 of them have died of AIDS-related disease (UNAIDS, 2018a).

The 90-90-90 target demands to end HIV by achieving $90 \%$ population knowing their status, 90\% HIV positive persons engaging in antiretroviral and $90 \%$ people living with HIV on antiretroviral treatment virally suppressed. It is not easy to achieve; the target needs to improve knowledge and reduce stigma by inserting sufficient knowledge (Maddali, Gupta, \& Shah, 2016). The programs focused specifically for key populations are aimed to provide evidence-based recommendation and increasing awareness of the HIV issues and needs (WHO, 2017). In most studies it was reported there was a wide variety of HIV-related intervention types (Faust \& Yaya, 2018). Health education of HIV-related information has been recognized to deliver remarkable outcomes in improving HIV knowledge, diagnosis and treatment (Martínez Sanz et al., 2019), also contributing in reducing stigma (Nyblade et al., 2019).

It has been noticed that the state of HIV knowledge improvement is growing, but the trend is still minimal. A study in Sub-Saharan Africa found only close to half of the research population retained comprehensive HIV knowledge (Chan \& Tsai, 2018). In accessing HIV-related information, key populations often face a complex challenge. The lack of guidance and follow-up of information, discriminatory acts among information providers, uncomfortable services and inadequacy of privacy insurance are the common reasons for key populations to ignore HIVrelated information seeking (Liu et al., 2016). In Indonesia, HIV knowledge is considered low with only 11.37 per 1000 population among aged 15-24 (UNAIDS, 2018b). It is crucial to assess the implementation gap in providing HIV-related information to boost the reach of key population in its acquisition. The evaluation of data is important to guide the HIV response in providing comprehensive and high quality performance of information providers (Hakim et al., 2018).

HIV-specific health literacy also contributes as important marking in the HIV behavior and decision of the key populations. Interventions are improving the health literacy of people living with HIV with low health literacy and bringing up better health behavior and outcomes (Wawrzyniak, Ownby, McCoy, \& Waldrop-Valverde, 2013). Health literacy drives health cognition, decision and behavior; poor health literacy will lead to lack of access to healthcare services and appropriate treatments, deriving from poor health education (Palumbo, 2015). The role of
HIV health education is vital in terms of developing the health literacy of the people living with HIV. HIV health literacy is an important mediator between HIV-related information and the outcomes (Tique et al., 2017). One of the notable HIV specific health literacy interventions is health education by using technology, known as e-health literacy. It is proven to promote HIV-related knowledge, medication adherence and individual self-management of the people living with HIV (Perazzo, Reyes, \& Webel, 2017).

In the current time, there are various new and innovative ways to confront the HIV epidemic. These interventions have been developed and implemented with the focus to increase individual knowledge, risk perception and motivation to avoid risky behavior. HIV health education has been conducted by using various methods to contribute to antiretroviral adherence and viral suppression (Wawrzyniak et al., 2013). Evaluation is necessary to build better capacity of the healthcare system in providing information and care for the populations. Evaluation also criticized the learning focus of the community development (Phillips et al., 2019). Evaluation of HIV health education interventions is crucial to drive better understanding in facing the challenges and to redesign more effective strategies in the future. Evaluation also creates better capture of complex information (Iskarpatyoti, Lebov, Hart, Thomas, \& Mandal, 2018). The comprehensive tools to record HIV knowledge remain lacking and there is a need to design comprehensive assessment (Hooshyar et al., 2017). Evaluation of the interventions to boost HIVrelated knowledge and literacy is an important measure to break through the obstacles. This study aimed to evaluate the experience of people living with HIV in acquiring HIV-related information.

\section{MATERIALS AND METHODS}

The design of the study was using qualitative study with phenomenological approach. This type of research design provides thick description of the phenomenon experienced by the people living with HIV in acquiring HIV-related information. This study interpreted the narrative situation of the information access for people living with HIV. This design was used to fully understand the uniqueness and concreteness of the representation of the HIV information access situation in the healthcare system according to the subjects' perspective. It will illustrate and individualize the genuine life experience of the people living with HIV in acquiring HIV related information. This study aimed to explore the complex and varied life experiences of people living with HIV in acquiring HIV-related information. It is expected to describe the particular form of interaction between people living with HIV and the healthcare system available regarding to HIV-related information. 
Table 1. Participant Characteristic

\begin{tabular}{cccccc}
\hline Participant Code & $\begin{array}{c}\text { Age } \\
\text { (years old) }\end{array}$ & Education & $\begin{array}{c}\text { Length of Disease } \\
\text { (in years) }\end{array}$ & Risk Population & Gender \\
\hline P1 & 29 & High School & 10 & IDU & Male \\
P2 & 30 & Elementary & 9 & IDU & Male \\
P3 & 31 & Junior High & 7 & Heterosexual & Male \\
P4 & 32 & Junior High & 7 & IDU & Male \\
P5 & 34 & High School & 7 & Prisoner & Male \\
P6 & 34 & High School & 7 & IDU & Male \\
P7 & 34 & High School & 5 & Prisoner & Male \\
P8 & 34 & Bachelor & 5 & Heterosexual & Female \\
P9 & 39 & High School & 7 & IDU & Male \\
P10 & 41 & Bachelor & 2 & IDU & Male \\
P11 & 22 & High School & 1 & MSM & Male \\
P12 & 31 & Diploma & 1 & MSM & Male \\
\hline
\end{tabular}

*IDU= Injecting Drug User

*MSM= Men Who Have Sex with Men

The study was conducted in Jakarta, Indonesia, by involving a non-government organization in HIV activism. Jakarta has 38 active non-government organizations and foundations, which entail to the HIV movement arrangement. Two notable nongovernment organizations were enlisted as prospective participants for the study. This qualitative study used purposive sampling method to choose participants to contribute in the research. The participants were considered as commonly knowing the research situation and providing an overview of life experiences in acquiring HIV-related information. Qualitative research does not require a rigid standard in terms of a minimum sample, but the number participants depends on the repetitive information presented. Data saturation examines the maximum participants that could be used for the research. The participants' criteria of the study were people living with HIV who have experienced healthcare service utilization, obtained HIV-related information, be willing to tell and consent to the research issue. The study used 12 participants whom provided narrative data of how people living with HIV acquire HIVrelated information.

The data collection in this study used in depth interviews with open-ended and semi-structured questions to all participants by the primary author. All data were recorded to tape recorder for verbal data and field notes for non-verbal expressions. The conversation took 30-45 minutes for each participant with a comfortable atmosphere in a dedicated room, open posture, private one-on-one interview and appropriate tone of speech. The questioning was triggered by asking how do people living with HIV acquire HIV-related information. The interview terminated when the data attained the information depth justified by the researcher as the instrument itself. The conversation ended by ensuring the physical and psychological condition of the participant. The data saturation marked by the repetition of information at 12 participants. The recorded data were then transferred into a soft computer file and saved in a specific and secured folder. Afterwards, the data were listened to repeatedly and shifted into a verbatim transcript. The transcripts and field notes were combined to complement the suitability of the data collected.

The transcripts were then sorted to find significant statements of the participants. These were then classified into categories, which were grouped into themes and subthemes. The themes were written in a thoughtful and representative narrative form, to make it easy to understand the experience. At the end, the research concluded four consequential themes. The analysis and the results were obliged to the qualitative data validities by ensure credibility, transferability, dependability, and conformability. This study was committed to the ethical guidelines and consideration in all research activities. Ensuring that no one was harmed or obtained negative impacts was crucial. This research strictly provides autonomy, beneficence, non-maleficence, confidentiality and justice. This study also committed to protect the participants involved. This study was reviewed by the Universitas Indonesia Ethical Council Committee and declared as ethically feasible to be conducted. The study concluded four consequential themes describing how people living with HIV acquire HIV-related information.

\section{RESULTS}

The participants in this study were 12 people living with HIV using healthcare services in Jakarta, Indonesia. The 12 participants participated voluntarily in in-depth interviews conducted during the research process. The 12 participants acknowledged their positive status and performed openness to be involved in the study and in 
cooperatively answering the questions during interview. Participants did not express objections or unwillingness in providing information in semistructured questions. All quoted texts in the manuscript were originally in Bahasa Indonesia and translated into English to fulfill publication requirements. The characteristics of the participants are displayed in Table 1 below (attached at the last page of the manuscript).

The study found four consequential themes: nongovernment organizations play a major role in HIV education, peers are a comfortable platform to discuss, it is all over the media and healthcare personnel are a source of knowledge. The details of each theme are explained as follows:

\section{Theme 1: Non-government Organizations Play a Major Role in HIV Education}

A bon-government organizations (NGO) was recognized as a platform which contributed in HIVrelated information for the most participants. They realized their risky behavior and what would be the consequences for them. Non-government organization provided them with essential information and knowledge related to HIV. The NGO interacted with participants through HIV seminars conducted by the organization. Also, the organization actively came to participants to deliver the message and information. The organization activists offered strong advice to prevent disease transmission and pointed out the importance of HIV testing to get knowledge of the participants' serostatus. One participant admitted that he was persuaded to go for a voluntary counselling test after the organization member approached him and made him understand the potential threat of the disease. The statement of the participant is documented below:

"At that time, as I remember there was a foundation, I guess, which I didn't really know the details, but I was sure it was related to the HIV activism movement. They came to us and explained everything about the risks and the importance of 'VCT' (Voluntary Counselling Test). They said they also provided it and asked us to do the check. Afterwards I was found to be positive." (P1)

Another participant told that he was really aware of the situation because one member of the organization came to him and explained the details of HIV. Then, with a gentle smile and rounded eyes, he recommended him to access the VCT in the healthcare facility nearby, as, recalling his expression, the participant commented as follows:

"So, this member of the organization was explaining it (HIV-related information) completely to me. It made me understand quite a bit though about the disease. He recommended me to check my status by accessing the VCT in the nearby healthcare facility. He gave me the contact and I went for a status check." (P2)

Another participant also shared the same experience. This participant said that he went to a HIV seminar held by the organization. Of his own volition, he decided to gain more knowledge about the disease and got to know the risks that he might have. He explained:

"I saw there was a free Seminar about HIV disease in a flyer back then conducted by a HIV NGO. It had been my curiosity at that time, I guess I had the risk, but I was not sure. So, I went to the seminar and got a full understanding that my risks were real." (P7)

\section{Theme 2: Peers are a Comfortable Platform to Discuss}

Four participants in this study stated that they acquired HIV related information from their peers. They affirmed that peers were an important circle in HIV-related information distribution. Peers optimally constructed their understanding of the disease and acknowledged them as a person with a wide spectrum. They felt accepted in considering themselves as an alter ego of their peers. Peer provided them with palpable experience and information so they felt connected to each other. Peers are a platform that allows them to express what they feel freely and without boundaries. The participants may discuss the hidden situation and information that often make them shy to tell others in terms of the secrecy. Peers also become an important role model for the participants to see the whole truth of the disease and the intricacy of HIV-related knowledge. Below is the statement of a participant:

"Back then, I had a friend, a childhood friend. Eventually he came with his secret story, which shocked me. He told me that he had HIV, after that I could not resist my own situation. I asked him so many things and he tried to make me understand by explaining all the information and then I realized I should have a check. He convinced and accompanied me to the Public Health Center nearby." (P1).

Another participant also told the same experience. He knew the information from his friend, who told him of a place to get a check. "...My friend told me don't be afraid, just go to 'Pro' (name of a notable private laboratory) they often not bother our lives that much..." (P5). Another participant also said the same thing. He knew a friend that might have sufficient information about HIV. He felt free to speak about the situation and curiosity that he had. He admitted that he never got a negative judgment from his friend, which made him very relieved. Through his friend's experience, the information he provided was also easy and comprehensive to understand. Passionately speaking, the participant said as follows: "I heard one of my friends had the same thing, and he must know many more things than. I approached him and he told me everything I needed to know. I hid nothing, then I went to the hospital that he also went to." (P4).

\section{Theme 3: It is All Over the Media}

All of the participants disclosed that the media also gives them information insight about HIV. Even though it was not enough information to convince them, they acknowledged it was quite helpful in transmitting HIV-related information. The media 
provided them brief and straightforward information that led them to access more HIV knowledge and information. Printed media, such as posters, flyers, newspapers and magazines, were the resources to get the information. Online media and website based made it easier for them to obtain such information. One participant states that he got the information from printed media such as poster and billboard. It briefly gave him the essential information about HIV. "When I walked around, sometimes I found a printed poster on the wall that told about HIV. I stopped for a while and read. I could feel the risks in me, I knew it. Also, on the billboard they also put the information there, not much but enough for a basic understanding." (P2)

Another participant affirmed that he got the information online from the electronic media on the internet. He tried to surf the information and there are very many resources if you want to seek HIVrelated Information. With a smirking smile, the participant told as follows:

"There are so many of them (HI- related information) on the internet, you could just click and you will find it easily. There are websites that completely tell you about the disease and I guess it is also provided by the NGO." (P3)

\section{Theme 4: Healthcare Personnel as Source of Knowledge}

Four of the participants also commented that they got the HIV-related information from the healthcare personnel. Healthcare personnel actively came to them directly and distributed the knowledge by themselves. They approached the participants at their 'hot spot' group gathering places. They realized that it might be a regular program made by the healthcare providers to reach out to the key populations. The healthcare personnel convinced the participants because they had sufficient knowledge and knew everything about HIV. They felt that they were the experts. Healthcare personnel also knew them appropriately because had been interacting with them for quite some time. One of the participants said: "The healthcare personnel came to us at that time. They explained about the risks and the disease. They seemed very expert about this. We got convinced, eventually and they also provided VCT and then we tried. That time, I then knew my status was positive." (P8)

Another participant told that ,after all the risks that they have been taking it was useful to have relevant information from other sources. They believed that the doctor and nurses convinced them to take a test and they obtained all the important and relevant information.

"I went to the doctor and asked more about myself. He explained many things to me and I got convinced. He asked me to get tested, and I did." (P11)

"I met the nurse; he told me anything that he knew about HIV. I believed in him, He explained it in such detail. Every information I've got from anywhere, I always cross-check on him. It feels relieving when I talk to him to justify any information I've got." (P12).

\section{DISCUSSION}

The study tells us the access of HIV-related information is now broadened and well-provided. Key populations may reach all necessary information by addressing various choices. The active or nonactive delivery ways used by the providers have equipped high-risk behavior population with basic essential knowledge. It is expected that, with certain knowledge, this will lead to better-desired outcomes of the disease prevention, treatment and care. Finer understanding of a population's perspective on HIV health education is important to get to know which are the best ways of delivery to improve HIV knowledge (Stonbraker et al., 2018). The participants on the study acknowledge HIV non-government organizations contribute in a large scale. Nongovernment organizations focusing on HIV are recognized as outstanding community lead groups to respond to health challenges and gaps (Lo, 2018). Non-government organizations have contributed in HIV progressive changes till the current time (Wang et al., 2016). The struggles that have been proved by this institution are undoubted. Study acknowledges that non-government organizations implement a holistic approach in all program activities, ensuring confidentiality, nurturing professionals and cultural competence, and strictly preserving equality and empathy. Non-government organizations focus their work by maintaining preventive implementation through a progressive empowerment health education approach (Berenguera et al., 2011).

The participants in this study realizes that peers are a safe space to gain more information. Peer-led HIV programs and activities are also a key step to improve access to information that leads to HIV eradication desired outcomes. A peer HIV knowledge delivery program significantly enriches key populations' knowledge. A study in highly stigmatized male sex workers in Africa proved a significant improvement of the knowledge of prevention behaviors. Peers also improve HIV prevention initiative coverage among key populations (Geibel, King'ola, Temmerman, \& Luchters, 2012). The essential knowledge provided by peers will influence key populations' decision and behavior. It also notably known that peer led programs increase significantly the degree of HIV testing among key populations. Previous study highlighted the changing numbers of key population engaging in HIV testing (Shangani et al., 2017). Peer education assigns key population with sufficient increase in knowledge of risk reduction through condom use, sexual transmission of HIV and transmission through sharps (Faust \& Yaya, 2018). Peers also help in achieving treatment engagement and antiretroviral compliance (Genberg et al., 2016). Peers are considered as a platform that overcomes the stigma often felt by the key population (Hall et al., 2017). Peers also build 
perpetuated social norms that justify HIV testing behavior of key populations' inner circle (Witzel, Weatherburn, Rodger, Bourne, \& Burns, 2017). Social network influences HIV testing behavior in key population, and peers persuade and provide assistance in all testing process activities (Conserve, Alemu, Yamanis, Maman, \& Kajula, 2018). In the Indonesia context, a study also found a narrative finding that people living with HIV determined their HIV healthcare access seeking behavior and healthcare function depended on social support (Setyoadi, 2013). Peer support also boosts the autonomy and self-determination of people living with HIV among Indonesian migrant workers (Nursalam, Yusuf, Widyawati, \& Asmoro, 2015)

The study found the media as an accessible platform to obtain HIV-related information. Media certainly take a role in becoming an integral part of HIV-related information distribution in the community. Accessing media strongly influences knowledge and the face of HIV education. Media are positively associated with HIV knowledge and awareness about transmission and prevention (Jung, Arya, \& Viswanath, 2013). Through technological improvement, the media can be accessed by anyone. Technology increases exposure among certain population and is considered as a significant predictor of HIV knowledge (Muhammad Hamid, Tamam, \& Nizam Bin Osman, 2020). Media provides the key population with an interactive yet understandable interface in the urban settings and shape the variable as HIV knowledge predictors for urban population (Bekalu \& Eggermont, 2014). Media becomes a platform to boost creative and innovative information delivery. Innovative digital improvisation in media delivery of HIV-related information has proved cost effectiveness in information distribution with large-scale coverage (Daher et al., 2017). Varies media options give the key populations freedom of choice to choose what is best for them. The individual approach of social media also marked a new trend of interventional strategies in HIV eradication activities (Tso, Tang, Li, Yan, \& Tucker, 2016). The media has also proved its contribution by showing positive impacts in changing prevention behavior (Bertrand, O'Reilly, Denison, Anhang, \& Sweat, 2006), HIV testing ( Wang et al., 2019), and adherence monitoring (Bychkov \& Young, 2018).

The healthcare providers also play a substantial role in providing information among participants. The rapid progress of healthcare services is also changing HIV programs and activities overlook. Healthcare providers are now accessible by the population to seek help and information. In a study, HIV risk populations admitted that healthcare personnel are moving forward to serve the HIV patients with equal treatments, more valued relationship, social support and confidentiality assurance (Stutterheim et al., 2014). Patient-centered care has also become a new focus trend in order to optimize HIV working progress. Providing access, uses and education of key population are the main variables in developing and deploying HIV-related interventions. Coordinated patient focus care is essential to build empowering situations among affected populations (Dixon \& Kaneshiro, 2012). Healthcare services delivery by healthcare personnel faces many factors for improvement. Training, working experience, appropriate timetable plans are a necessity to be developed. A primary prevention practice is encouraged to push down new transmission disease in the population (Davis et al., 2016). In forming an appropriate attitude in delivering services among kin, healthcare providers have now become important to attract more people to engage healthcare services for obtaining HIVrelated information (Abu Moghli, Al Habeesh, \& Abu Shikha, 2017). The limitation of the study found some participants found it difficult to express the qualitative narration of their experience. It required the communication competency of in-depth semistructured interviews of the interviewer.

\section{CONCLUSION}

This study showed a changing progress of HIV-related information delivery. The underpinning qualitative evaluation assures optimistic strategies need to be implemented and optimized years ahead in order to achieve 2030 goals. Maintaining the consequential pattern is crucial and developing better and strategic programs in HIV-related information delivery remains vital.

\section{ACKNOWLEDGEMENT}

We extend our gratitude to the Faculty of Nursing, Universitas Indonesia and Universitas Andalas for their technical and related support.

\section{REFERENCES}

Abu Moghli, F., Al Habeesh, S., \& Abu Shikha, L. (2017). Perception of HIV/AIDS Education at the Community Level in Jordan. Iranian Journal of Public Health, 46(3), 301-307. Retrieved from https://pubmed.ncbi.nlm.nih.gov/28435815

Bekalu, M. A., \& Eggermont, S. (2014). Media use and HIV/AIDS knowledge: a knowledge gap perspective. Health Promotion International, 29(4), https://doi.org/10.1093/heapro/dat030

Berenguera, A., Pujol-Ribera, E., Violan, C., Romaguera, A., Mansilla, R., Giménez, A., \& Almeda, J. (2011). Experiences about HIV-AIDS preventivecontrol activities. Discourses from nongovernmental organizations professionals and users. Gaceta Sanitaria, 25(3), 184-190. https://doi.org/10.1016/j.gaceta.2010.10.015

Bertrand, J. T., O’Reilly, K., Denison, J., Anhang, R., \& Sweat, M. (2006). Systematic review of the effectiveness of mass communication programs to change HIV/AIDS-related behaviors in developing countries. Health Education Research, 21(4), 567- 
597. https://doi.org/10.1093/her/cyl036

Bychkov, D., \& Young, S. (2018). Social media as a tool to monitor adherence to HIV antiretroviral therapy. Journal of Clinical and Translational Research, 3(Suppl 3), 407-410. Retrieved from https://pubmed.ncbi.nlm.nih.gov/30873489

Chan, B. T., \& Tsai, A. C. (2018). HIV knowledge trends during an era of rapid antiretroviral therapy scaleup: an analysis of 33 sub-Saharan African countries. Journal of the International AIDS Society, 21(7), e25169-e25169. https://doi.org/10.1002/jia2.25169

Conserve, D. F., Alemu, D., Yamanis, T., Maman, S., \& Kajula, L. (2018). "He Told Me to Check My Health": A Qualitative Exploration of Social Network Influence on Men's HIV Testing Behavior and HIV Self-Testing Willingness in Tanzania. American Journal of Men's Health, 12(5), 11851196.

https://doi.org/10.1177/1557988318777674

Daher, J., Vijh, R., Linthwaite, B., Dave, S., Kim, J., Dheda, K., ... Pai, N. P. (2017). Do digital innovations for HIV and sexually transmitted infections work? Results from a systematic review (1996-2017). BMJ Open, 7(11), e017604e017604. https://doi.org/10.1136/bmjopen2017-017604

Davis, T., Teaster, P. B., Thornton, A., Watkins, J. F., Alexander, L., \& Zanjani, F. (2016). Primary Care Providers' HIV Prevention Practices Among Older Adults. Journal of Applied Gerontology: The Official Journal of the Southern Gerontological Society, 35(12), 1325-1342. https://doi.org/10.1177/0733464815574093

Dixon, B. E., \& Kaneshiro, K. (2012). Improving Access to HIV and AIDS Information Resources for Patients, Caregivers, and Clinicians: Results from the SHINE Project. Online Journal of Public Health Informatics, $\quad 4(1)$, ojphi.v4i1.3849. https://doi.org/10.5210/ojphi.v4i1.3849

Faust, L., \& Yaya, S. (2018). The effect of HIV educational interventions on HIV-related knowledge, condom use, and HIV incidence in subSaharan Africa: a systematic review and metaanalysis. BMC Public Health, 18(1), 1254. https://doi.org/10.1186/s12889-018-6178-y

Geibel, S., King'ola, N., Temmerman, M., \& Luchters, S. (2012). The impact of peer outreach on HIV knowledge and prevention behaviours of male sex workers in Mombasa, Kenya. Sexually Transmitted Infections, 88(5), 357-362. https://doi.org/10.1136/sextrans-2011-050224

Genberg, B. L., Shangani, S., Sabatino, K., Rachlis, B., Wachira, J., Braitstein, P., \& Operario, D. (2016). Improving Engagement in the HIV Care Cascade: A Systematic Review of Interventions Involving People Living with HIV/AIDS as Peers. AIDS and Behavior, 20(10), 2452-2463. https://doi.org/10.1007/s10461-016-1307-z

Haakenstad, A., Moses, M. W., Tao, T., Tsakalos, G., Zlavog, B., Kates, J., ... Dieleman, J. L. (2019). Potential for additional government spending on
HIV/AIDS in 137 low-income and middle-income countries: an economic modelling study. The Lancet HIV, 6(6), e382-e395. https://doi.org/10.1016/S2352-3018(19)300384

Hakim, A. J., MacDonald, V., Hladik, W., Zhao, J., Burnett, J., Sabin, K., ... Garcia Calleja, J. M. (2018). Gaps and opportunities: measuring the key population cascade through surveys and services to guide the HIV response. Journal of the International AIDS Society, 21 Suppl 5(Suppl Suppl 5), e25119-e25119. https://doi.org/10.1002/jia2.25119

Hall, B. J., Sou, K.-L., Beanland, R., Lacky, M., Tso, L. S., Ma, Q., ... Tucker, J. D. (2017). Barriers and Facilitators to Interventions Improving Retention in HIV Care: A Qualitative Evidence MetaSynthesis. AIDS and Behavior, 21(6), 1755-1767. https://doi.org/10.1007/s10461-016-1537-0

Hooshyar, S. H., Shahesmaeili, A., Faramani, R. S., Khajehkazemi, R., Nasirian, M., Sharifi, H., \& Kamali, K. (2017). 85: KNOWLEDGE, ATTITUDE AND PRACTICE OF HIV/AIDS: A SYSTEMATIC REVIEW AMONG KEY POPULATIONS AT RISK FOR HIV INFECTION IN IRAN. BMJ Open, 7(Suppl 1), bmjopen-2016-015415.85.

https://doi.org/10.1136/bmjopen-2016015415.85

Iskarpatyoti, B. S., Lebov, J., Hart, L., Thomas, J., \& Mandal, M. (2018). Evaluations of Structural Interventions for HIV Prevention: A Review of Approaches and Methods. AIDS and Behavior, 22(4), 1253-1264 https://doi.org/10.1007/s10461-017-1997-x

Januraga, P. P., Reekie, J., Mulyani, T., Lestari, B. W., Iskandar, S., Wisaksana, R., ... Kaldor, J. M. (2018). The cascade of HIV care among key populations in Indonesia: a prospective cohort study. The Lancet HIV, 5(10), e560-e568. https://doi.org/10.1016/S2352-3018(18)301486

Jung, M., Arya, M., \& Viswanath, K. (2013). Effect of media use on HIV/AIDS-related knowledge and condom use in sub-Saharan Africa: a crosssectional study. PloS One, 8(7), e68359-e68359. https://doi.org/10.1371/journal.pone.0068359

Liu, Y., Osborn, C. Y., Qian, H.-Z., Yin, L., Xiao, D., Ruan, Y., ... Amico, K. R. (2016). Barriers and Facilitators of Linkage to and Engagement in HIV Care Among HIV-Positive Men Who Have Sex with Men in China: A Qualitative Study. AIDS Patient Care and STDs, 30(2), 70-77. https://doi.org/10.1089/apc.2015.0296

Lo, C. Y.-P. (2018). Securitizing HIV/AIDS: a game changer in state-societal relations in China? Globalization and Health, 14(1), 50. https://doi.org/10.1186/s12992-018-0364-7

Maddali, M. V., Gupta, A., \& Shah, M. (2016). Epidemiological impact of achieving UNAIDS 9090-90 targets for HIV care in India: A modelling study. BMJ Open, 6(7), 1-6. https://doi.org/10.1136/bmjopen-2016-011914 
Martínez Sanz, J., Pérez Elías, M. J., Muriel, A., Gómez Ayerbe, C., Vivancos Gallego, M. J., Sánchez Conde, M., ... DRIVE 03, Opt. W. and F. S. G. (2019). Outcome of an HIV education program for primary care providers: Screening and late diagnosis rates. PloS One, 14(7), e0218380-e0218380. https://doi.org/10.1371/journal.pone.0218380

Muhammad Hamid, A., Tamam, E., \& Nizam Bin Osman, M. (2020). Relationships between Media Exposure and Knowledge, Attitude, and Practice on HIV/AIDS: A Cross Sectional Survey of Adolescent Islamiyya Girls in Nigeria. Health Communication, 35(4), 419-429. https://doi.org/10.1080/10410236.2018.15649 60

Nursalam, Yusuf, A., Widyawati, I. Y., \& Asmoro, C. P. (2015). Peningkatan Kemandirian Perawatan Tenaga Kerja Indonesia (Tki) Yang Terinfeksi Hiv Melalui Pengembangan Model Pemberdayaan Keluarga Dan Peer Group Support. Jurnal Ners, 10(March 2016), 265-271.

Nyblade, L., Stockton, M. A., Giger, K., Bond, V., Ekstrand, M. L., Lean, R. M., ... Wouters, E. (2019). Stigma in health facilities: why it matters and how we can change it. BMC Medicine, 17(1), 25. https://doi.org/10.1186/s12916-019-1256-2

Palumbo, R. (2015). Discussing the Effects of Poor Health Literacy on Patients Facing HIV: A Narrative Literature Review. International Journal of Health Policy and Management, 4(7), 417-430. https://doi.org/10.15171/ijhpm.2015.95

Perazzo, J., Reyes, D., \& Webel, A. (2017). A Systematic Review of Health Literacy Interventions for People Living with HIV. AIDS and Behavior, 21(3), 812821. https://doi.org/10.1007/s10461-016-13296

Phillips, G., Lindeman, P., Adames, C. N., Bettin, E., Bayston, C., Stonehouse, P., ... Greene, G. J. (2019). Empowerment Evaluation: A Case Study of Citywide Implementation within an HIV Prevention Context. The American Journal of Evaluation, 40(3), 318-334. https://doi.org/10.1177/1098214018796991

Setyoadi. (2013). Pengalaman ODHA Mendapatkan Dukungan Sosial dalam Menjalani Kehidupan Sehari-hari di Malang Raya. Jurnal Ners, 8(2), 240252.

Shangani, S., Escudero, D., Kirwa, K., Harrison, A., Marshall, B., \& Operario, D. (2017). Effectiveness of peer-led interventions to increase HIV testing among men who have sex with men: a systematic review and meta-analysis. AIDS Care, 29(8), 1003-1013.

https://doi.org/10.1080/09540121.2017.12821 05

Stonbraker, S., Smaldone, A., Luft, H., Cushman, L. F., Lerebours Nadal, L., Halpern, M., \& Larson, E. (2018). Associations between health literacy, HIVrelated knowledge, and information behavior among persons living with HIV in the Dominican Republic. Public Health Nursing (Boston, Mass.), 35(3),

166-175. https://doi.org/10.1111/phn.12382

Stutterheim, S. E., Sicking, L., Brands, R., Baas, I., Roberts, H., van Brakel, W. H., ... Bos, A. E. R. (2014). Patient and provider perspectives on HIV and HIV-related stigma in Dutch health care settings. AIDS Patient Care and STDs, 28(12), 652665. https://doi.org/10.1089/apc.2014.0226

Tique, J. A., Howard, L. M., Gaveta, S., Sidat, M., Rothman, R. L., Vermund, S. H., \& Ciampa, P. J. (2017). Measuring Health Literacy Among Adults with HIV Infection in Mozambique: Development and Validation of the HIV Literacy Test. AIDS and Behavior, 21(3), 822-832. https://doi.org/10.1007/s10461-016-1348-3

Tso, L. S., Tang, W., Li, H., Yan, H. Y., \& Tucker, J. D. (2016). Social media interventions to prevent HIV: A review of interventions and methodological considerations. Current Opinion in Psychology, 9, 6-10.

https://doi.org/10.1016/j.copsyc.2015.09.019

UN. (2019). Special edition: progress towards the Sustainable Development Goals. Retrieved from https://undocs.org/E/2019/68

UNAIDS. (2014). To help end the AIDS epidemic. United Nations, 40. Retrieved from http://www.unaids.org/sites/default/files/medi a_asset/90-90-90_en.pdf

UNAIDS. (2018a). Country factsheets China | 2018 HIV and AIDS Estimates| 2018 HIV People living with HIV Coverage of adults and children. Unaids, 1-6. $\quad$ Retrieved from https://aidsinfo.unaids.org/\%0D

UNAIDS. (2018b). Country factsheets China | 2018 HIV and AIDS Estimates| 2018 HIV People living with HIV Coverage of adults and children. Unaids. Retrieved from https://aidsinfo.unaids.org/\%0D

UNAIDS. (2019). Global HIV and AIDS statistics 2019 Fact sheet. Global HIV and AIDs Ststistics, World AIDS Day 2019 Fact Sheet, 1(June), 1-6.

UNAIDS. (2020). SUMMARY OF STRATEGY DEVELOPMENT PROCESS AND Phase I : Review of the current strategy ( UNAIDS 2016-2021 On the Fast- Track to end AIDS ), its implementation , and the results obtained Scope of the Review 20162021 Strategy Result Areas.

Wang, D., Mei, G., Xu, X., Zhao, R., Ma, Y., Chen, R., ... Hu, Z. (2016). Chinese non-governmental organizations involved in HIV/AIDS prevention and control: Intra-organizational social capital as a new analytical perspective. Bioscience Trends, $10(5)$, 418-423. https://doi.org/10.5582/bst.2016.01134

Wang, L., Podson, D., Chen, Z., Lu, H., Wang, V., Shepard, C., ... Mi, G. (2019). Using Social Media To Increase HIV Testing Among Men Who Have Sex with Men - Beijing, China, 2013-2017. MMWR. Morbidity and Mortality Weekly Report, 68(21), 478-482.

https://doi.org/10.15585/mmwr.mm6821a3

Wawrzyniak, A. J., Ownby, R. L., McCoy, K., \& WaldropValverde, D. (2013). Health literacy: impact on the health of HIV-infected individuals. Current 
HIV/AIDS Reports, 10(4), 295-304. https://doi.org/10.1007/s11904-013-0178-4

WHO. (2017). Policy Brief Hiv Prevention , Diagnosis , Treatment and Care for Key Populations. Geneva. Retrieved from https://www.who.int/publicationsdetail/consolidated-guidelines-on-hivprevention-diagnosis-treatment-and-care-forkey-populations

Witzel, T. C., Weatherburn, P., Rodger, A. J., Bourne, A. H., \& Burns, F. M. (2017). Risk, reassurance and routine: a qualitative study of narrative understandings of the potential for HIV selftesting among men who have sex with men in England. BMC Public Health, 17(1), 491. https://doi.org/10.1186/s12889-017-4370-0

World Health Organization. (2019). Progress report on HIV, viral hepatitis and sexually transmitted infections 2019. Accountability for the global health sector strategies, 2016-2021. Geneva: WHO/CDS/HIV/19.7). Licence: CC BY-NC-SA 3.0 IGO. 